Welding thermomechanically-strengthened materials is accompanied with certain difficulties in terms of loss of strength characteristics in the zone of thermal influence. This issue can be resolved by using the technological welding schemes that include fusion of materials in a narrow contact area. One such technological scheme is electron beam welding, which is currently widely used to fabricate structures from refractory and chemically active materials. One of the main advantages of the electron beam welding process is a small quantity of heat input, which leads to the formation of narrow zones of melting and thermal influence and, as a result, minor deformities in the structure of the material. The welded joint can structurally be divided into several zones, which differ in the morphological characteristics of the structure. The most interesting, in terms of ensuring the quality of the joint, are the boundaries between the zones. It has been shown that the use of local heating sources, which is the case at electron beam welding, leads to the migration of the boundaries of grains. As a result, clear intersections, fusion lines, form at the boundaries between zones of the welded joint. The formation of the structural state of a welded joint is predetermined by the simultaneous course of several processes. First, a crystallization from the liquid state - the formation of a welded joint structure, as well as the boundary between a welded joint and the zone of thermal influence. Second, the phase-structural transformations in the solid state - a thermal impact zone, the boundary between a thermal impact zone and the main metal. Given this, one should note that the geometry and quality of joints at electron beam welding are more interrelated than in other welding techniques. Thus, one of the main parameters that ensure the quality of a welded joint is the structural state of the material that forms during welding

Keywords: electron beam welding, structural state, low-carbon micro-alloyed steels, welded joint zones

\section{FEATURES IN THE FORMATION OF THE STRUCTURAL STATE OF LOW- CARBON MICRO-ALLOYED STEELS AFTER ELETRON BEAM WELDING}

\author{
Dm y tro Laukhin \\ Doctor of Technical Sciences, Professor* \\ Valeri Poznyakov \\ Doctor of Technical Sciences, Senior Researcher, \\ Corresponding Member of the NAS of Ukraine, \\ Deputy Director for Scientific and Technical Work*** \\ Valery Kostin \\ Doctor of Technical Sciences, Leading Researcher \\ Department of Physical and Chemical Research of Materials No. 022*** \\ O l ex a nder B e k t ov \\ $\mathrm{PhD}$, Associate Professor \\ Department of Fundamental and Natural Sciences** \\ Natali a Rot t \\ Corresponding author \\ $\mathrm{PhD}$, Associate Professor \\ Department of Design, Technical Aesthetics and Design \\ Dnipro University of Technology \\ D. Yavornytskoho ave., 19, Dnipro, Ukraine, 49005 \\ E-mail: natalyrott@gmail.com \\ Yuli i S I u p s a \\ Postgraduate Student* \\ Lilia Dadiverina \\ $\mathrm{PhD}$, Associate Professor \\ Department of Planning and Organization of Production** \\ O I g a L i b y mova-Zinchenko \\ $\mathrm{PhD}$, Associate Professor \\ Department of Chemistry and Occupational Safety \\ Volodymyr Dahl East Ukrainian National University \\ Tsentralnyi ave., 59-a, Severodonetsk, Ukraine, 93400 \\ *Department of Materials Science and Materials Processing** \\ **Prydniprovska State Academy of Civil Engineering and Architecture \\ Chernyshevskoho str., 24a, Dnipro, Ukraine, 49005 \\ $\star * \star E$. O. Paton Electric Welding Institute \\ of the National Academy of Sciences of Ukraine \\ Bozhenka str., 11, Kyiv, Ukraine, 03680
}

How to Cite: Laukhin, D., Poznyakov, V., Kostin, V., Beketov, O., Rott, N., Slupska, Y., Dadiverina, L., Lyubimova-Zinchenko, O. (2021). Features in the formation of the structural state of low-carbon micro-alloyed steels after eletron beam welding. Eastern-European Journal of Enterprise Technologies, 3 (12 (111)), 25-31 doi: https://doi.org/10.15587/1729-4061.2021.234783
1. Introduction

Low-carbon sheet structural steel of strength class C490 is mostly used at present as a material for welding construc- tion structures. However, the higher buildings and facilities require that steels with a higher level of strength (C590 and above) should be applied [1,2]. That necessitates mode detailed research related to both improving the operational 
properties of the material for welding construction structures and analyzing the manufacturability and energy efficiency of production of the structures themselves (welding, installation modes, etc.) [3]. Thus, improving the manufacturability and energy efficiency of production and the use of welding construction structures by advancing the structural state and welding regimes is relevant both from a scientific and the economic and national point of view.

Obtaining reliable joints under open construction conditions is difficult or impossible as regards the use of stationary machines and devices, so the requirements for welding processes are of particular significance [4].

The greatest importance in ensuring the strength and reliability of a welded joint is rendered to specific processes that evolve after the crystallization of the joint in the nearjoint zone. The value of the thermal impact zone depends on the technique and technology of welding, as well as the properties of welded metal [5].

It should be noted that the application of welding adds factors that are associated with both the design of welded joints and the technology of their manufacture. These factors, first of all, include the presence of stress concentrators associated with abrupt transitions from the main metal to the joint's metal, or from one element to another, which could reduce the reliability of a welded joint. The strongest influence is exerted by stress concentrators of this type to the structure exposed to an applied load [6].

It follows from above that ensuring the reliability of structures, which is to be understood as the likelihood of trouble-free operation before the onset of the limit state of destruction, is a relevant task for modern materials science.

\section{Literature review and problem statement}

Welding thermomechanically-strengthened materials is associated with some difficulties in terms of loss of strength characteristics in the zone of thermal influence. This issue can be resolved by using such technological welding schemes, which include the fusion of materials in a narrow contact area. One of these technological schemes is electron beam welding, which is widely used in the fabrication of structures made from refractory and chemically active materials [7]. The advantages of the process of electron beam welding include a small amount of heat input, which leads to the formation of narrow zones of melting and thermal influence and, as a result, minor deformities in the structure of the material. That is why the use of electron beam welding in the production of construction metal structures is promising in terms of obtaining joints with a set of mechanical properties at the level of the main metal.

Thus, given the features of the technological process of electron beam welding, one of the main parameters that ensure the quality of a welded joint is the structural state of the material formed during welding.

As shown in paper [8], the main idea of electron beam welding is to convert the kinetic energy of the directed beam of electrons in the local area of the material into thermal. At the same time, the process is carried out by melting the edges of the metal with a sharply focused flow of electrons accelerated by an electric field with the potential difference of $\geq 10 \ldots 100 \mathrm{kV}$ [9]. As a result, the electron beam provides a high level of power in the local treated area. On the other hand, according to the results reported in work [10], the features of physical and mechanical processes that occur during the formation of a welded joint during electron beam welding lead to the formation of specific defects that can reduce the operational characteristics of the joints. For example, paper [11] gives the data on a study into the use of electron beam welding in the manufacture of turbine blades. However, there are unresolved issues related to the mechanisms for reducing the hardness of a welded joint and the near-joint zone. One of the options for improving the quality of a welded joint may be the development of new, improved technological welding schemes. This approach was used by the authors of work [12] who propose an updated technological regime of electron beam welding, which prevents the formation of the near-root defects in a welded joint. Paper [13] suggests a mode of electron beam welding, which includes a programmable distribution of energy of the electron beam, which reduces the porosity and stress of deformation in welded joints. However, such a concept requires the modernization of existing equipment and, as a result, would increase the cost of finished articles. On the other hand, the authors of work [14] note that the presence of porosity in a welded joint significantly reduces the limit of fatigue strength. Paper [15] shows that the geometry and quality of the joints during electron beam welding are more interconnected than in other welding techniques. Given this, it is possible to conclude that the quality of the joint at electron beam welding is determined by several factors. First, it is a set of technological and energy parameters of the process. Second, the peculiarities of phase transformations, that is, the patterns in the formation of the structural state of the joint zones, due to the action of the local heat source during electron beam welding.

Obtaining reliable and high-quality welded joints of highstrength steels after electron beam welding is a relevant scientific task. At the same time, the most important is the detailed study of the influence of specific parameters of the structure formed in the metal of joints, a thermal impact zone, and the main metal, on the strength and crack resistance of these joints. Taking into consideration that some areas of the thermal impact zone of the obtained welded joints are small, determining their mechanical properties in the conventional way is not always possible. To this end, it is necessary to use evaluation methods based on the results from experimental studies into the structure using high-quality raster electron microscopy.

\section{The aim and objectives of the study}

The purpose of this study is to ensure the quality of welded joints as a result of a detailed analysis of the structural state of the joint's metal, the zone of thermal influence, and the near-boundary zones after electron beam welding of low-carbon micro-alloyed steels. This would make it possible to investigate the effect of electron beam welding on the formation of the structural state of the welded joint zones and, from a structural point of view, to evaluate the quality of a welded joint for these steels.

To accomplish the aim, the following tasks have been set:

- to conduct a metallographic study into the structural state of low-carbon micro-alloyed steels 09G2S, 10HSND, 10G2FB;

- to analyze the morphological features of the structure of a welded joint;

- to investigate the morphology of the structural state of the welded joint after electron beam welding of low-carbon micro-alloyed steels 09G2S, 10HSND, 10G2FB. 


\section{The study materials and methods}

The low-carbon micro-alloyed steels 09G2S, 10HSND, 10G2FB, manufactured by TOV Metinvest Holding, Ukraine were chosen as the material for this study. Raster electron microscopy at the scanning electron microscope REM-106I (manufactured by TOV SELMI, Ukraine) was used in our work. Experimental welding was carried out at the equipment of the Institute of Electric Welding named after E. O. Paton, NAS of Ukraine. Electron beam welding was performed at the installation UL-144 (Ukraine), equipped with the power supply ELA-60/60 (Ukraine), the welding gun CF-4 (Ukraine), and the beam control device SU-220 (Ukraine). Welding was carried out according to the following parameters: accelerating voltage, $-60 \mathrm{kV}$; beam current, $70 \mathrm{~mA}$; circular scan diameter on the surface at a distance of $100 \mathrm{~mm}$ from a welded article is $2 \mathrm{~mm}$; welding speed, $5.5 \mathrm{~mm} / \mathrm{s}$.
The analysis of our set of metallographic studies reveals that the use of continuous controlled rolling leads to the formation of two main structural components in the structure of metal products: ferrite and perlite (Fig. 1). At the same time, the ferrite phase has a more finegrained structure compared to the steel structures of 09G2S, 10HSND, 10G2FB after conventional industrial modes [17]. The perlite component of the structure, based on the analysis of its morphology, can be attributed to quasi-eutectoid [18].

\section{2. Analysis of morphological features of the struc-} ture of a welded joint

In terms of morphological features of the structure of a welded joint, and based on work [16], the welded joint zone was divided into zones with different structural state. Schematically, these zones are shown in Fig. 2.

\section{Results of studying the structural state of low-carbon micro-alloyed steels}

5. 1. Metallographic study of the structural state of the low-carbon micro-alloyed steels 09G2S, 10HSND, 10G2FB

The chemical composition of the low-carbon micro-alloyed steels 09G2S, 10HSND, $10 \mathrm{G} 2 \mathrm{FB}$ is given in Table 1 .

These grades of steel were subjected to thermomechanical machining according to the manufacturing scheme of continuous controlled rolling [16]. The microstructure of samples after the continuous controlled rolling is shown in Fig. 1.

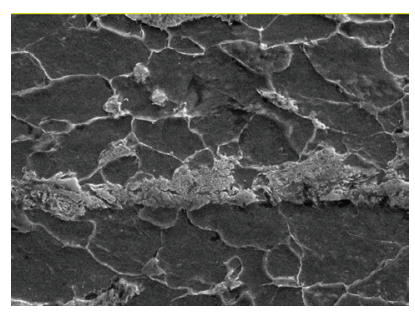

$a$

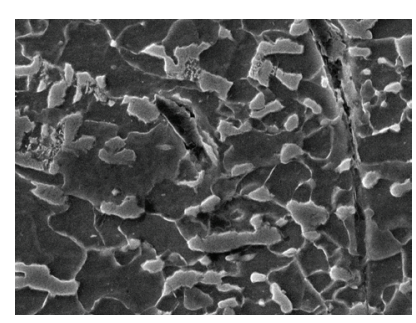

c

Fig. 1. Microstructure of the examined steels: $a-09 \mathrm{G} 2 \mathrm{~S}$; $b-10 \mathrm{HSND} ; c-10 \mathrm{G} 2 \mathrm{FB}$

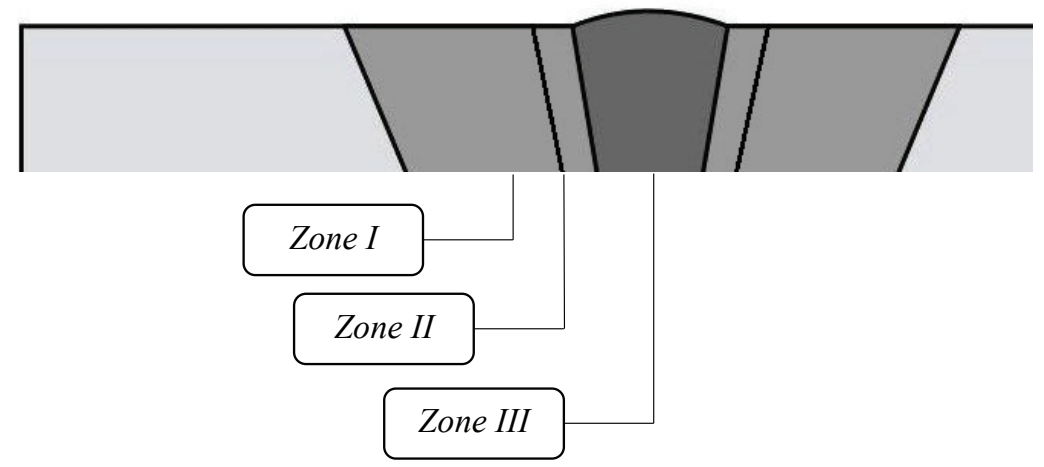

Fig. 2. Welded joint zones

Zone I: the main metal, which, in this area, is partially melted in the process of welding and is a mixture of solid and liquid phases. The surfaced metal has a columned coarse-grained structure characteristic of cast steel.

Zone II: the supercooling in this area ensures the formation of the structure of the material with a characteristic coarse-grained structure. In this zone, there are structural components with pronounced rail morphology: bainite, martensite, widmannstätten ferrite.

In zone III, there is an incomplete re-crystallization of the steel heated to the temperature between critical points. In this area, after cooling, along with large grains of ferrite, small grains of ferrite and spheroidized perlite are formed.

There are no structural changes in steel in zone IV. Otherwise, recrystallization is observed in this area.

The microstructural studies reported in this work were based on this scheme, that is, zones I, II, III were studied (Fig. 2).

The results of studying the microstructure of a welded joint's zones after electron beam welding are summarized and shown in Fig. 3.

Table 1

Chemical composition of steels 09G2S, 10HSND, 10G2FB

\begin{tabular}{|c|c|c|c|c|c|c|c|c|c|c|c|}
\hline Steel & $\mathrm{C}$ & $\mathrm{Si}$ & $\mathrm{Mn}$ & $\mathrm{Ni}$ & $\mathrm{S}$ & $\mathrm{P}$ & $\mathrm{Cr}$ & $\mathrm{V}$ & $\mathrm{N}$ & $\mathrm{Cu}$ & $\mathrm{Fe}$ \\
\hline 09G2S & to 0.12 & $0.5-0.8$ & $1.3-1.7$ & to 0.3 & to 0.035 & to 0.03 & to 0.3 & to 0.12 & to 0.008 & to 0.3 & Remaining \\
\hline 10HSND & to 0.12 & $0.8-1.1$ & $0.5-0.8$ & $0.5-0.8$ & to 0.04 & to 0.035 & $0.6-0.9$ & - & to 0.008 & $0.4-0.6$ & - \\
\hline 10G2FB & $0.08-0.13$ & $0.15-0.35$ & $1.6-1.8$ & to 0.3 & to 0.035 & to 0.03 & to 0.3 & $0.05-0.12$ & - & - & - \\
\hline
\end{tabular}




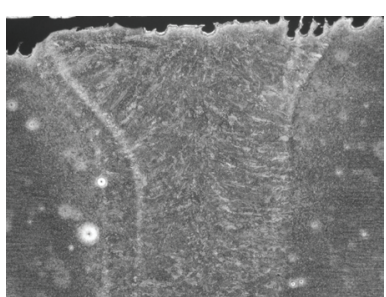

$a$

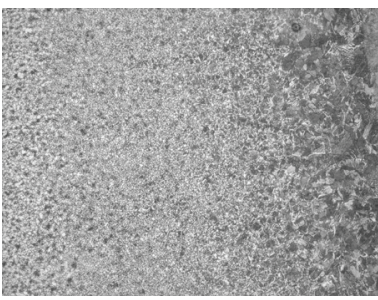

d

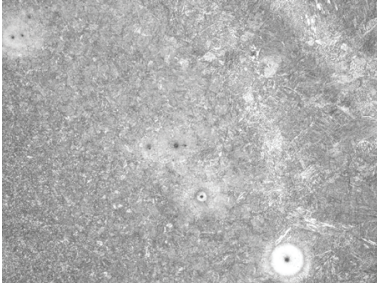

$b$

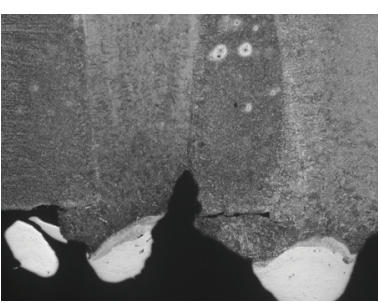

e
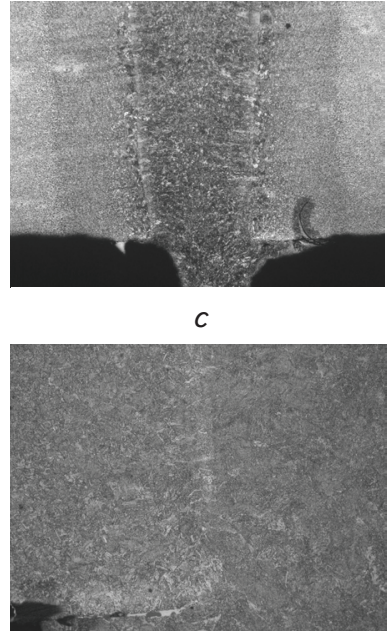

$f$

Fig. 3. Microstructure of a welded joint after electron beam welding: $a, b-09 \mathrm{G} 2 \mathrm{~S} ; c, d-10 \mathrm{HSND} ; e, f-10 \mathrm{G} 2 \mathrm{FB}$

Our analysis of the obtained data shows that the formation of a structural state in zone I has a directional character, which is due to the presence of a temperature gradient.

As a result, the structure is column crystals that grow from the surface of molten metal to the center of the joint (Fig. 3, $a, c, e$ ). In the steels 10HSND and 10G2FB, the center of the joint demonstrates equilibrium crystallites (Fig. 3, c,e).

Fig. $3, b, d, f$ shows the clearly defined boundaries of the interface between zone I and zone II. This element of the structure of the welded joint, according to the literary sources [5], is termed the line or boundary of fusion.

The metal in zones II and III have a microstructure different from the main metal, which corresponds to the reheating modes to temperatures above $\mathrm{Ac}_{3}$ and subsequent cooling at different speeds.
5. 3. Analyzing the morphology of the structural state of a welded joint after electron beam welding

In order to generalize the data acquired from our micro-structural studies, the general patterns of a welded joint were built, shown in Fig. 4-6.

Fig. 4, 5 show that when forming the structural state of a welded joint, phase transformations occur, which are a consequence of the local influence of the heat from a welding source. As a result, when approaching zone I, the reheating temperature is approaching the melting point. Aging at such temperatures ensures the formation of fine-grained austenite, which is further transformed according to the bainite mechanism. When distancing from zone I, the heating temperature of the metal is much lower, but higher than $\mathrm{Ac}_{3}$, so the size of the austenite grain would be lower than that near the joint. Thus, during cooling, an even more dispersed ferrite-bainite structure is formed than in zone II.

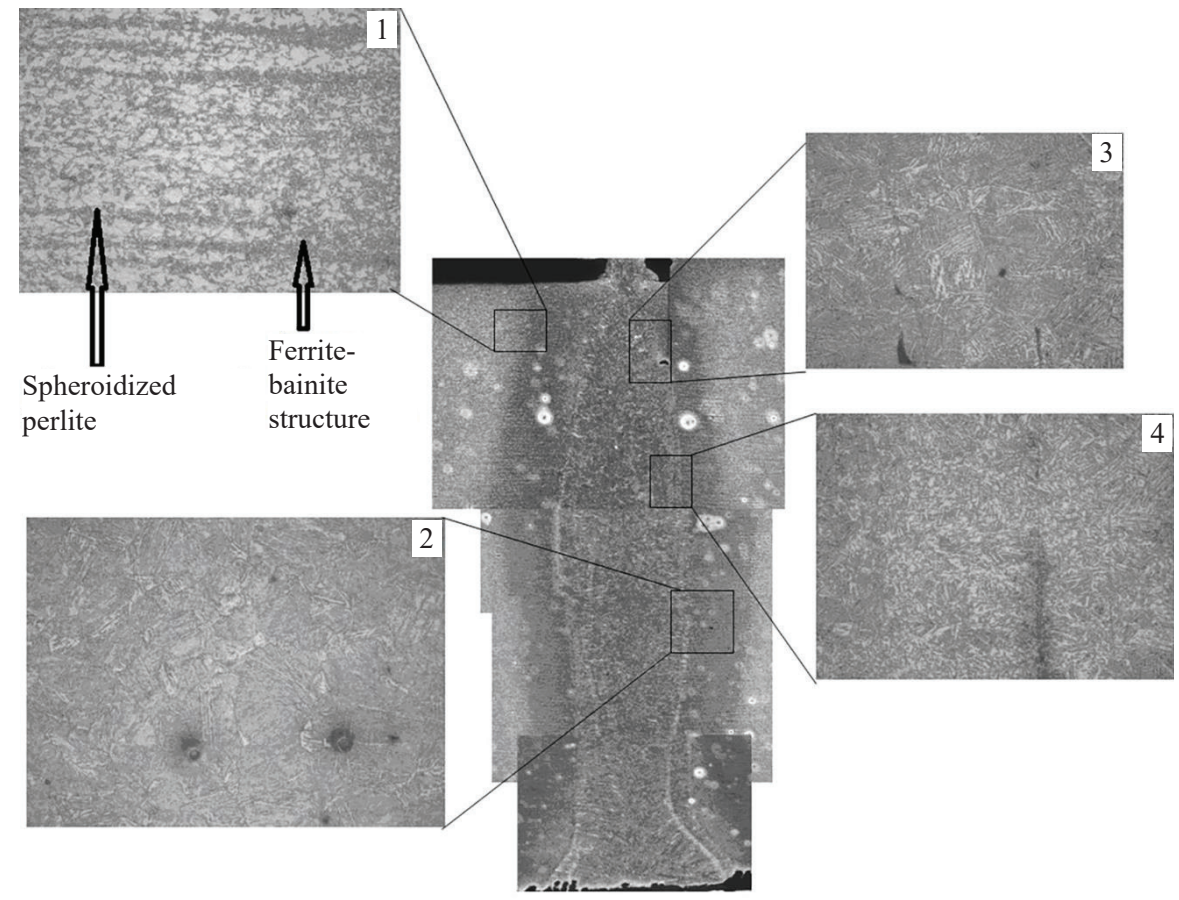

Fig. 4. The general view and structure of the welded joint: steel 09G2S: 1 - boundary between zones III and IV (Fig. 2); 2 - near-joint zone (close to zone I); 3 - joint's structure; 4 - boundary between zones 1 and 2 (Fig. 2) 


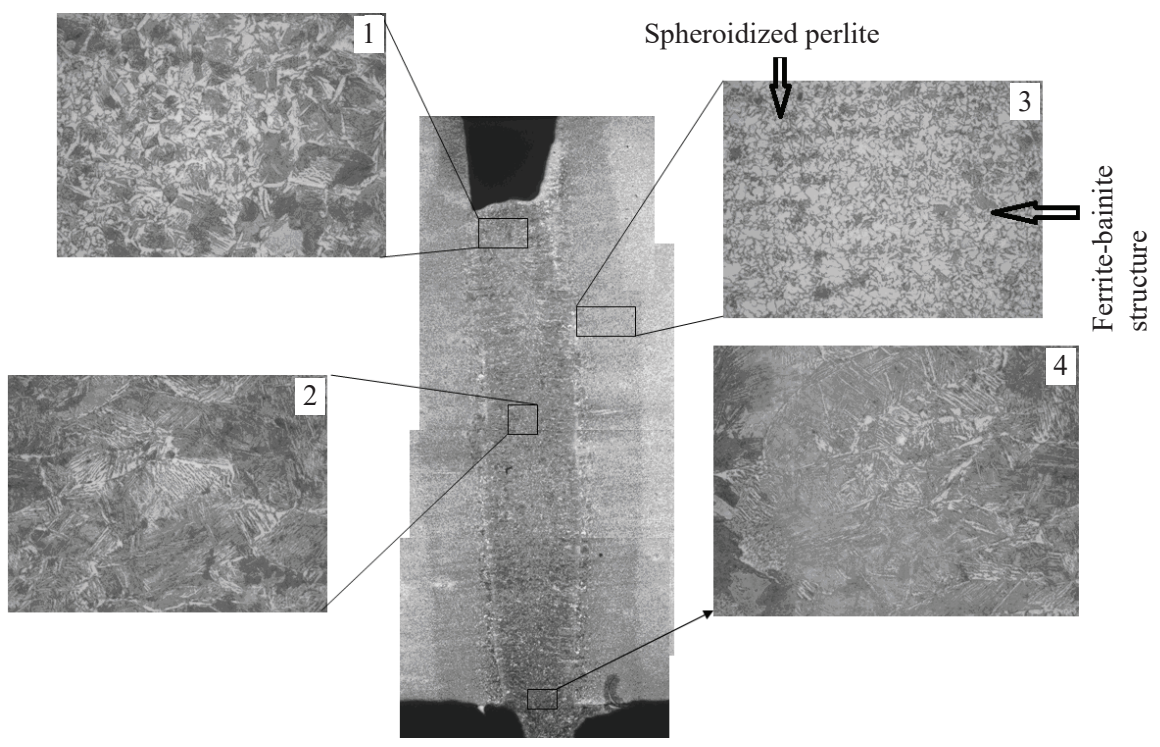

Fig. 5. The general view and structure of the welded joint: steel 10HSND: 1 - zone I (equilibrium crystals); 2 - zone I, the presence of a cast structure; 3 - boundary between zones III and IV (the presence of a transition layer between the ferritebainite structure and the area where spheroidized ferrite forms); 4 - structure of the root of the welded joint

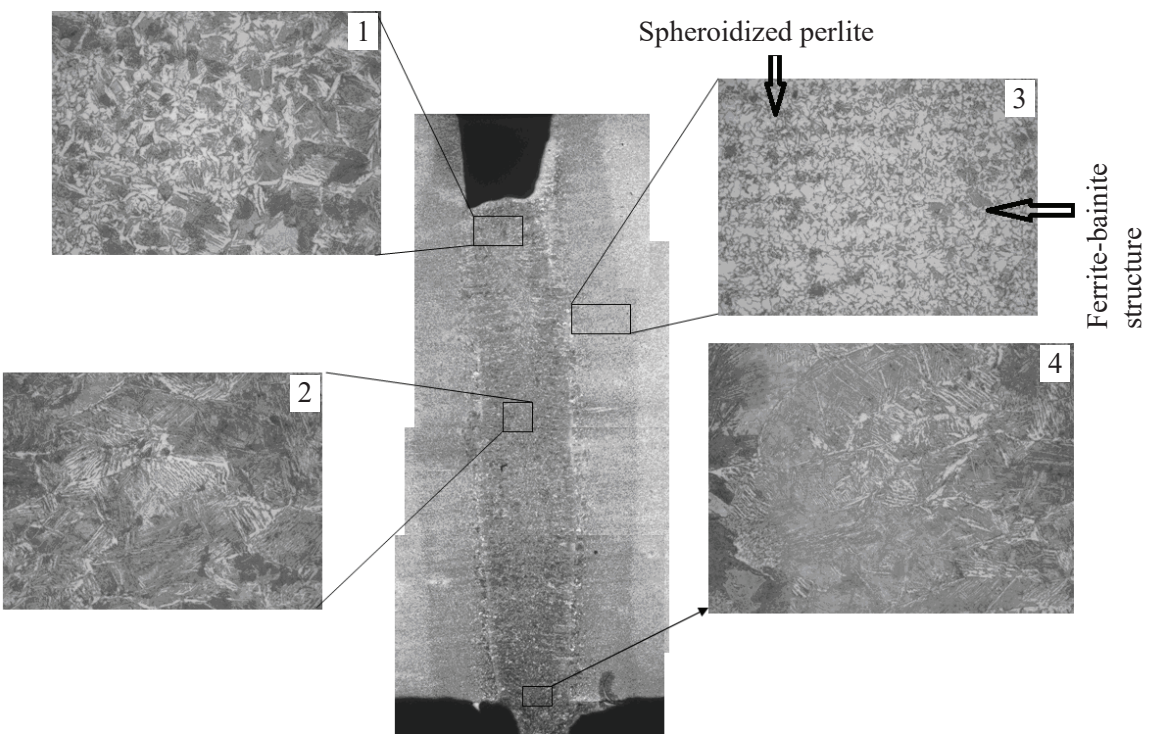

Fig. 6. The general view and structure of the welded joint: steel 10G2FB: 1 - zone III structure (reheating area to the temperature of $\mathrm{Ac}_{3}+50$, ferrite and bainite structure); 2 - boundary of zone I and II (melting zone); 3 - fusion zone at the root joint

\section{Discussion of results of studying the structural state of low-carbon micro-alloyed steels after electron beam welding}

The analysis of our set of studies shows that during electron beam welding, processes occur simultaneously, which are characteristic of both crystallization of metal from the liquid phase and of the phase transformations in a solid state. Due to the local heatwave, the main metal is melted in the upper part of the bath, and, in the lower one, there is already crystallization of the joint and the structural transformations in a solid state. At the same time, the formation of the structural state of zone III is primarily due to the desire of the system to reduce the level of free energy (Fig. 4-6). Accordingly, there are changes in the location of the boundaries of grains, which leads to a decrease in the total length of the boundaries, and, as a result, to a decrease in the level of surface energy. Thus, the structural state of zone II and zone III is formed by the formation of a secondary granular-boundary structure and its alignment in terms of reducing the overall level of free energy.

The formation of the fusion line (Fig. $3, b, d, f$ ) is due to the migration processes of the boundaries of grains that occur during cooling after welding. Boundaries are formed during structural transformations directly with the growth of primary crystals on the side of the joint and on the side of the main metal. The crystalline lattices of growing phases have an arbitrary orientation and their combination is accompanied by a significant deformation of the lattices, which causes the occurrence of an increased level of internal micro-strains. These processes directly depend on the heat input that occurs during welding, that is, the more local the welding source, the 
lower the multi-grain character and, as a result, the lower the degree of internal micro-strains.

Thus, the subject area of this study is to establish the influence of electron beam welding on the peculiarities in the formation of the structural state of a joint, the zone of thermal influence, and the near-boundary zones of low-carbon micro-alloyed steels.

Given this, the improvement of our results and conducting new research into this area would make it possible to develop improved welding modes for high-strength steels, taking into consideration the structural state and operating conditions of rolled metal.

A given area of research is to be advanced by establishing the quantitative and qualitative link: the structural state of the material - welding mode - the thin structure of the welded zones - the general characteristics of welding construction metal structures. That could improve the quality of welding building structures made domestically by refining the structural state of the material and the theoretical selection of the manufacturing regime (welding) taking into consideration the conditions for further operation of finished articles.

\section{Conclusions}

1. Our set of studies into the structure of the steels 09G2S, 10HSND, and 10G2FB, which were produced according to the technological scheme of controlled rolling, has shown that the structural state is characterized by the presence of a dispersed ferrite-perlite structure. That is due to the peculiarities of the technological scheme of continuous controlled rolling, namely the deformation of metal in the intercritical temperature region. The formation of a dispersed structural state ensures an increase in the strength characteristics of the output metal products, which has a positive effect on the formation of the structural state of zones during further welding.

2 . The set of studies reported here has demonstrated that the welded joint can structurally be divided into several zones, which differ in the morphological characteristics of the structure. This fact is explained by the speed at which the processes of phase and structural transformations occur in each of the zones. At the same time, the most interesting, in terms of ensuring the quality of the joint, are the boundaries between the zones. As shown by our studies, the use of local heating sources, which is the case during electron beam welding, leads to the migration of the boundaries of grains. As a result, at the boundaries between the zones of the welded joint clear boundaries of the intersection, fusion lines, are formed.

3 . The structural state of the welded joint of low-carbon low-alloyed steels 09G2S, 10HSND, 10G2FB after electron beam welding was investigated. The formation of the structural state of the welded joint is due to the simultaneous course of several processes. First, a crystallization from the liquid state - the formation of a welded joint's structure and the boundary between a welded joint and the zone of thermal influence. Second, the phase-structural transformations in the solid state - a thermal impact zone, the boundary between a thermal impact zone and the main metal. Thus, the structure of zones is formed according to the processes of structure formation, which correspond to the modes of re-heat treatment of metal when heated to temperatures above $A c_{3}$, and subsequent cooling at different speeds.

\section{References}

1. Bol'shakov, V. I., Razumova, O. V. (2008). Ispol'zovanie staley povyshennoy prochnosti v novom vysotnom stroitel'stve i rekonstruktsii. Dnepropetrovsk: Porogi, 216.

2. Zherbin, M. M., Bol'shakov, V. I. (2000). Novaya kontseptsiya modernizatsii i nadstroyki suschestvuyuschih maloetazhnyh zhilyh zdaniy do lyubogo kolichestva etazhey. Dnepropetrovsk: Gaudeamus, 50.

3. Bailey, N., Wright, M. D. (1993). Weldability of High Strength Steels. Welding and Metal Fabrication, 61 (8), 389-396.

4. Paton, B. E. (1999). Problemy svarki na rubezhe vekov. Avtomaticheskaya svarka, 1, 4-14.

5. Laukhin, D., Pozniakov, V., Beketov, O., Rott, N., Shchudro, A. (2020). Analysis of the Effects of Welding Conditions on the Formation of the Structure of Welded Joints of Low-Carbon Low-Alloy Steels. Key Engineering Materials, 844, 146-154. doi: https://doi.org/10.4028/www.scientific.net/kem.844.146

6. Gubenko, S. (2015). Nemetallicheskie vklyucheniya i prochnost' staley. Fizicheskie osnovy prochnosti staley. Dnepropetrovsk: Palmarium academic publishing, 471.

7. Loboda, P., Zvorykin, C., Zvorykin, V., Vrzhyzhevskyi, E., Taranova, T., Kostin, V. (2020). Production and Properties of ElectronBeam-Welded Joints on Ti-TiB Titanium Alloys. Metals, 10 (4), 522. doi: https://doi.org/10.3390/met10040522

8. Fedosov, A. V., Karpovych, E. V. (2015). Advanced aspects of electron-beam welding for high-strength titanium alloys. Aviatsionnokosmicheskaya tekhnika i tekhnologiya, 1 (118), 16-22.

9. Kostin, V., Taranova, T., Zvorykin, V. (2021). Fracture of Electron Beam Welding Joints of Titan Alloys. Solid State Phenomena, 316, 333-339. doi: https://doi.org/10.4028/www.scientific.net/ssp.316.333

10. Nazarenko, O. K., Grabin, V. F., Lokshin, V. E. (1974). Fiziko-metallurgicheskie osobennosti elektronnoluchevoy svarki sredneuglerodistyh staley. Avtomaticheskaya svarka, 4, 1-4.

11. Sharonov, N. I. (2010). Primenenie elektronno-luchevoy svarki v turbostroenii. Nauchno-tekhnicheskie vedomosti SPbPU, 3, $143-149$.

12. Bulatnikova, O. V., Mikhalchenkov, A. V. (2017). Specific defects in welded compounds and methods of their prevention. Aktual'nye problemy aviatsii i kosmonavtiki. Sektsiya «Svarka letatel'nyh apparatov i rodstvennye tekhnologii», 1, 389-391. 
13. Bulatnikova, O. V., Cheburashkin, S. A. (2016). Characteristic of process of electron beam welding. Aktual'nye problemy aviatsii i kosmonavtiki, 1, 419-421.

14. Grigoriev, V. V., Muravyev, V. I., Bakhmatov, P. V. (2019). Changes in the structure and microhardness of permanent joints of loadbearing structures made of titanium alloy VT23 by electron beam welding. Proceedings of Higher Educational Institutions. Machine Building, 1 (706), 20-28. doi: https://doi.org/10.18698/0536-1044-2019-1-20-28

15. Fouad, Y., Marouani, H. (2019). Fracture characteristics of dissimilar electron-beam welded joints between Cr-Mo steel and austenitic steel AISI 304. AIP Advances, 9 (4), 045211. doi: https://doi.org/10.1063/1.5090401

16. Laukhin, D., Beketov, O., Rott, N., Schudro, A. (2019). The Elaboration of Modernized Technology of Controlled Rolling Directed at the Formation of High Strengthening and Viscous Qualities in HSLA Steel. Solid State Phenomena, 291, 13-19. doi: https://doi.org/10.4028/www.scientific.net/ssp.291.13

17. DeArdo, A. (1995). Modern Thermomechanical Processing of Microalloyed Steel: A Physical Metallurgy Perspective. Proceedings of Microalloying 95 Conference. Pittsburgh, 15-33.

18. Beketov, A. V., Bol'shakov, V. I., Kuksenko, V. I., Suhomlin, G. D., Lauhin, D. V., Semenov, T. V. (2010). Obrazovanie i rost perlitnyh koloniy. Visnyk Prydniprovskoi derzhavnoi akademii budivnytstva ta arkhitektury, 1, 29-35. 